\title{
Problems of using flooded and morned areas on the example of the city district city of Tyumen region
}

\author{
Natalia Cherezova ${ }^{1, *}$ and Tatiana Avilova ${ }^{1}$ \\ ${ }^{1}$ Industrial University of Tyumen, 625001, Tyumen city, Russia
}

\begin{abstract}
One of the main conditions for the existence of people on earth is the preservation of soils, the improvement of their regime and properties. The rational use of the land fund depends on the intensity of the overgrowth of the land with birch, shrub, and weeds, as well as on the erosion of the land. If overgrowth at certain stages limits the growth of plants, interferes with soil cultivation, makes the territory unfavorable for agricultural work, then erosion determines a decrease in the fertile layer of soil and increases the division of the territory, reducing the productivity of land and involving it in the national economic turnover. In recent decades, Russia, as well as other countries of the world, has been characterized by increasing trends in land degradation, violations as a result of natural phenomena, economic and other activities, which are accompanied by an aggravation of the problem of food security.
\end{abstract}

\section{Introduction}

One of the most acute problems in the reclamation of Western Siberia is the secondary waterlogging of drained bogs, accompanied by degradation processes in biocenoses, the appearance of signs of gleying and the accumulation of undecomposed remains on the surface. Secondary waterlogging impairs the agronomic properties of soils and reduces their productivity. According to available data, 20-30 thousand hectares are additionally swamped annually on the West Siberian Plain. The most effective means aimed at minimizing negative processes is land reclamation. In the process of socio-economic transformations, a new economic system based on market relations has been created in the country: a variety of forms of ownership and payment for land use have been introduced; on the basis of the former collective and state farms, AO, KFH, SPK, LLC were created; the land acquired the status of real estate and is included in the turnover [3, 4, 8]. In the course of the reforms, the volume of work on land reclamation and soil protection from erosion has been reduced, and attention has been weakened to preserve and increase soil fertility. As a result, land degradation occurs: erosion and salinization of soils, overgrowth of agricultural land with forests and shrubs, and a decrease in the productivity of natural forage lands.

\footnotetext{
*Corresponding author: cherezovanv@tyuiu.ru
} 
If overgrowth at certain stages limits the growth of plants, interferes with soil cultivation, makes the territory unfavorable for agricultural work, then erosion determines a decrease in the fertile soil layer and increases the division of the territory, reducing the productivity of land and its involvement in the national economic turnover.

From the whole mass of types of damage or harm caused by negative processes of land use, it is possible to single out such types of damage as dismemberment of the territory, washout of the humus layer, deterioration of the hydrological regime and others, which in themselves do not lend themselves to economic assessment, but can be estimated indirectly [2], through the destruction of the soil cover, the decrease in the productivity of machinery and the productivity of agricultural crops.

\section{Methodology}

In the article, the author analyzes and discusses the problems of using the territory of flooding and waterlogging on the example of the urban district of the city of Tyumen.

In order to increase the productivity and sustainability of agriculture, land fertility, as well as create the necessary conditions for the involvement of unused and unproductive territories in agricultural circulation, land reclamation is carried out.

Soil reclamation in terms of its duration is probably comparable to the history of human civilization. The development of large irrigation systems, organized water use are closely related to the emergence of large slave states, the emergence of centralized management. In the basins of the Tejen and Murghab rivers, 10,000 BC. there was irrigation. Historical documents indicate that artificial irrigation was widely used more than 4000 years ago in Egypt, Mesopotamia, China, Urartu, India. In the valleys of the Tigris and Euphrates rivers, the remains of the largest irrigation canal Narvan have survived to this day, the construction of which belongs to the period of one of the most ancient civilizations that existed in Mesopotamia. The intensive development of land reclamation in Russia was initially associated with the activities of Peter I. He undertook drainage of swamps in connection with the development of the coast of the Gulf of Finland, the construction of St. Petersburg and other cities, fortresses, factories. However, in the post-Petrine period until the second half of the 19th century. work in the field of soil drainage in Russia was carried out on a very limited scale [5,7]. The abolition of serfdom and the rapid development of capitalism were the driving factor in land reclamation.

As of 2018, the Russian Federation has 9.47 million hectares of reclaimed land, including 4.69 million hectares of irrigated and 4.78 million hectares of reclaimed land. In agricultural production, 7.08 million hectares of reclaimed land are used for growing crops (75\% of the availability), including 3.89 million hectares of irrigated and 3.19 million hectares of drained land. The Ministry of Agriculture of Russia is in charge of 18.4 thousand hydraulic structures. These include the construction of 232 reservoirs, more than 2 thousand regulating hydroelectric systems, 42.3 thousand $\mathrm{km}$ of water supply and discharge canals, 3.4 thousand $\mathrm{km}$ of protective dams and other facilities.

At present, a significant part of the ameliorated land (over 3.5 million hectares) is in an unsatisfactory condition. More than half of the irrigation systems (2.4 million hectares) need reconstruction and technical re-equipment in order to improve safe operation and other measures.

The legislation of the Russian Federation in the field of land reclamation is represented by the Federal Law of 10.01.1996 N 4-FZ (as amended on 08.12.2020) "On land reclamation" and laws and other regulatory legal acts of the Russian Federation adopted in accordance with it, as well as laws and other regulatory legal acts of the constituent entities of the Russian Federation. The generally recognized principles and norms of international law and international treaties of the Russian Federation in the field of land reclamation are, 
in accordance with the Constitution of the Russian Federation, an integral part of the legal system of the Russian Federation. If an international treaty of the Russian Federation establishes other rules than those provided by the legislation of the Russian Federation in the field of land reclamation, the rules of the International Treaty are applied [1].

On the lands of settlements, the following negative processes are distinguished:

- natural (affecting the engineering and construction state of lands - these are deformations of the earth's crust, subsidence, flooding).

-natural-man-made (affecting the ecological and sanitary-hygienic state of lands - these are violations of soil acidity and alkalinity, soil degradation (decrease in fertility, erosion, desiccation, overconsolidation of the root layer, depletion and violation of the organoprofile, damage and destruction of the fertile layer, etc.) and for architectural and urban planning (relief change).

- technogenic (affecting the ecological and sanitary-hygienic state of lands - degradation of vegetation cover, reduction of greenery, littering, increase in the sealed area, contamination of soils and grounds with chemicals, contamination of soils and grounds with radioactive substances, noise pollution of lands, excess growth of electric and electromagnetic fields, land contamination by pathogenic microorganisms).

-social (affecting the architectural and urban planning state of land - this is a violation of urban planning standards, irrational organization of the territory, unauthorized construction, deterioration of the land balance, fragmentation of the existing land plots)

The most destructive effect on agricultural land is erosion, that is, the process of capturing soil particles and carrying them out by water or wind.

Negative processes lead to:

- reduction in the total area of agricultural land;

- reduction of the area of irrigated and drained lands, deterioration of their ameliorative condition and economic use;

- an increase in the negative balance of humus on arable land;

- soil contamination with heavy metals, radionuclides;

- an increase in areas with strongly acidic soils, on which agricultural production is limited.

Negative processes and phenomena in such disturbed territories are revealed not only during ground-based studies, but also during the analysis of Earth remote sensing data. Therefore, in geoecological studies, technologies based on the interpretation of aerospace images of different spatial and temporal resolutions are increasingly used

In the software product MapInfo, a map of the secondary swamping of the reclamation system of the [6,7]. Earth remote sensing materials ensure the reliability, efficiency and regularity of measuring the characteristics of the state of the natural environment. They are also the basis for organizing monitoring in remote and hard-to-reach, due to high swampiness, areas.

The territory of the south of the Tyumen region is extremely flat, poorly dissected and poorly drained. To this should be added a fairly close hydraulic connection of aquifers, contrasting climatic conditions, a high percentage of lakes, swamps and wetlands of mineral lands. Therefore, it was vital to carry out reclamation measures here.

Tarmanskaya geosystem was created (Fig. 1). By analyzing the images obtained from the Landsat series spacecraft, it was possible to establish that the area of secondary waterlogging in the territory of the reclamation system of the Tarmanskaya forest-lake-bog geosystem for the period under study increased on average by $4.248 \mathrm{~km}^{2}$ per year and at the time of the study was $84.96 \mathrm{~km}^{2}$ [7]. 


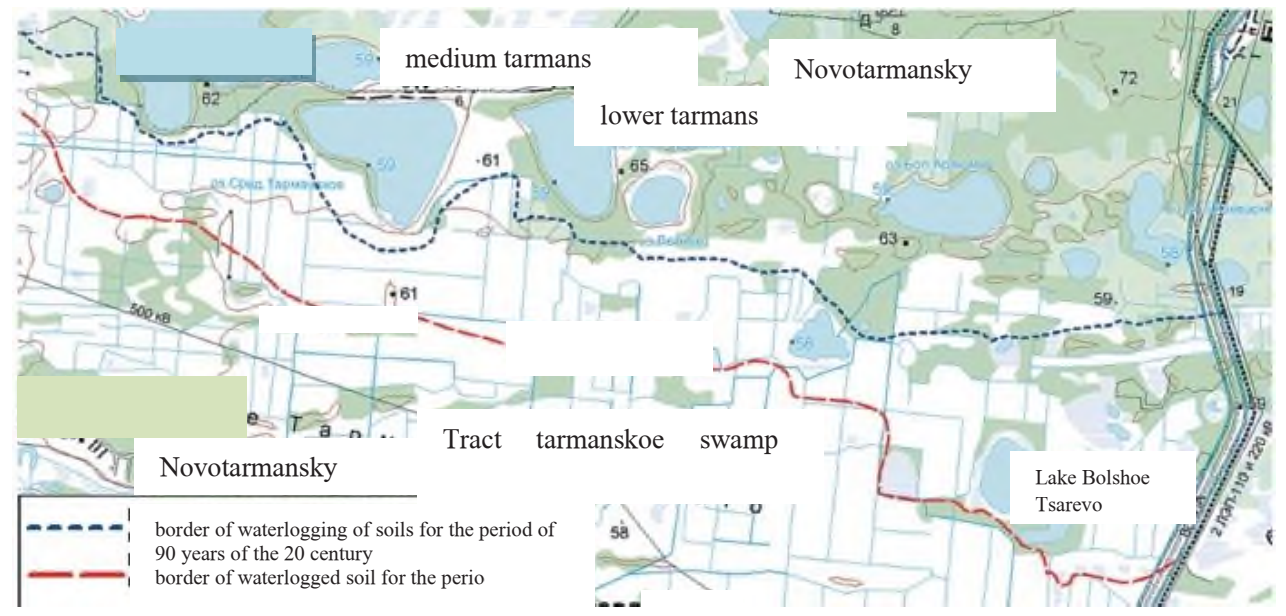

Fig. 1. Fragment of the secondary swamping map of the reclamation system of the Tarmanskaya geosystem M 1: 200,000.

Among the many environmental problems of the urban district of Tyumen, flooding and waterlogging of urban lands, taking into account its scale and intensity of development, is of priority importance, since it not only creates discomfort in living conditions, but also threatens the health of people and their very lives. The consequences of flooding are so serious that we can speak of a precedent in the city of an emergency situation, for the resolution of which urgent special engineering protective measures are required [9]. In Tyumen, 135 flooded areas have been identified, of which 55 are located in the Central Administrative District, 46 in Kalininsky, 25 in Leninsky and 9 in Vostochny. These include the Tura microdistrict, the so-called Staraya Zareka, microdistricts beyond the river, z. Vatutino, female Bereznyakovsky, Zh. Kazarovo, Zh.R. Tarmans, f. Cape, f. DOK, Plekhanovo microdistrict, territories along the Moscow and Chervishevsky tracts, Voinovka area. Interestingly, the maximum rise in water was observed in the spring of 1979, it was $915 \mathrm{~cm}$; in $1998-871 \mathrm{~cm}$; the third highest water level in the entire history of observations was reached in May 2016 and amounted to $868 \mathrm{~cm}$.

\section{Results and discussion}

As you know, in the Tyumen region since 2011, large families with three or more children have been allocated land for housing $[10,11]$. However, during the implementation process, it became clear that there is not enough suitable land for the implementation of this program. Therefore, it was decided to provide plots from lands of little use or practically unusable. Large tracts for these purposes were set aside between the Salair and Velizhansky tracts. 


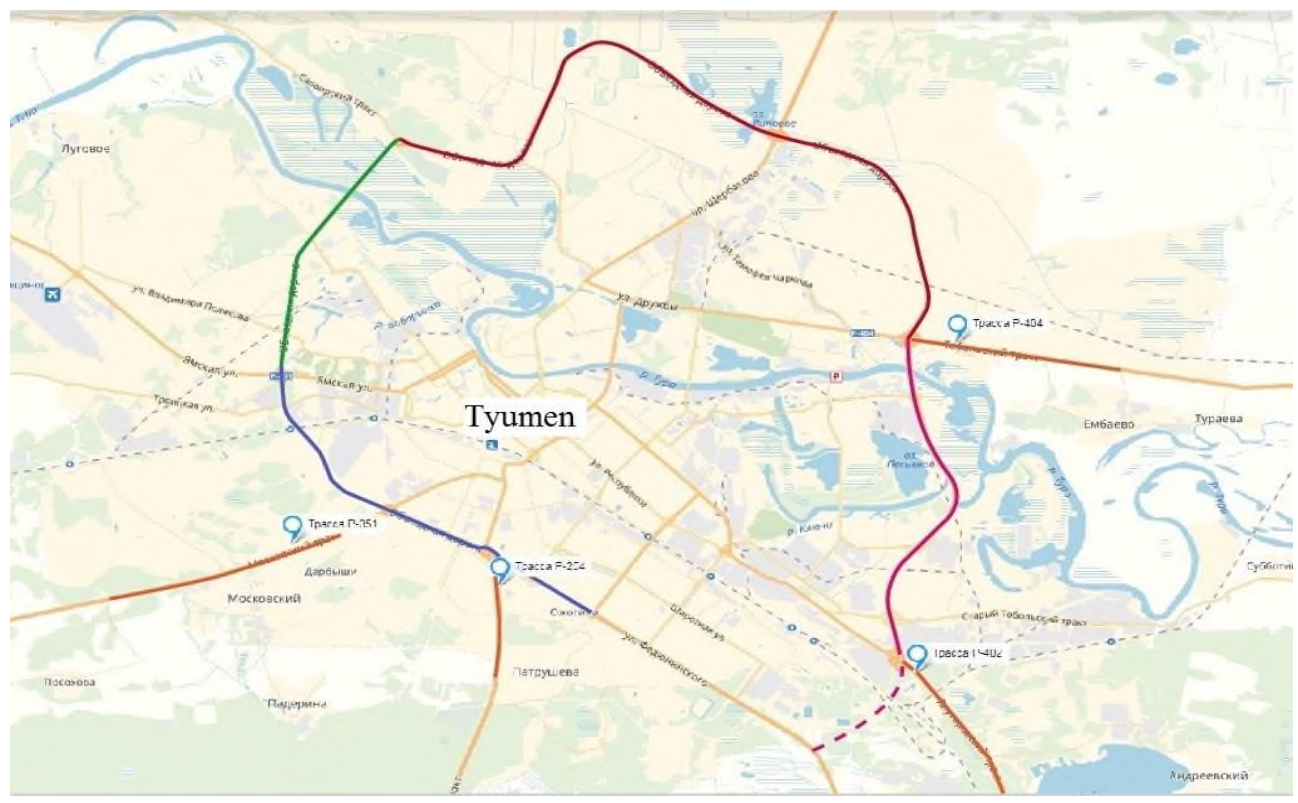

Fig. 2. Street and road network of the city of Tyumen.

The territory near the lake Bolshoye Tsarevo, which is part of the Novotormanskie wetlands complex [12]. Some are located on the territory of swamps, the other part is in the floodplain, where flooding often occurs. The study was carried out on the Tarmansky bog massif, lying on the second above-floodplain lacustrine-alluvial terrace of the river. Tours. Terraced bedding of the massif determines its elongated shape, oriented parallel to the main elements of the hydrographic network. The Tarmansky bog massif refers to the lowland type of bogs, in which the ground pressure type of water supply prevails (from 15 to $87 \%$ ) [12]. The length of the massif is $136 \mathrm{~km}$, the width ranges from 7 to $40 \mathrm{~km}$. The total catchment area is $2160 \mathrm{~km} 2$, directly occupied by the swamp $1240 \mathrm{~km} 2(57 \%)$. The average depth of peat throughout the bog is $2 \mathrm{~m}$. The age of peat at a depth of $25 \mathrm{~cm}$ is $1505 \pm 50$ years, at a depth of $65 \mathrm{~cm}-3685 \pm 40$ years, and the rate of peat accumulation is about $0.16 \mathrm{~mm} /$ year [7]. Part of the investigated bog massif was drained in the 60-80s. XX century. The reclaimed area is 272 hectares, of which 60 hectares are drained by pottery drainage with a depth of $0.9,1.2,1.5 \mathrm{~m}$ and distances between drains, respectively $8,24,40$ $\mathrm{m}$. The rest is drained by open canals with distances of 100, 150, 200 and $250 \mathrm{~m}$ [ ]. In the 90s. due to the lack of an operation service, repairs and maintenance of hydraulic structures were not carried out, drainage systems became unusable, and, along with natural processes, this caused a secondary swamping process, as evidenced by the data of routine observations.

As a result, most of this land was not used in any way. The families who received it cannot start building them. The reason lies in the disturbance of the drainage and reclamation system, as a result of which, for example, in the territory of the Tarmansky bog, secondary waterlogging occurs. Also, there may be several more reasons for the occurrence of a negative process in this territory. This could be:

- destruction and overgrowth of drainage network channels;

- overlapping of the drainage network canals with earthen dams and embankments (Fig. 3);

- construction of transport communications (Fig. 4). 


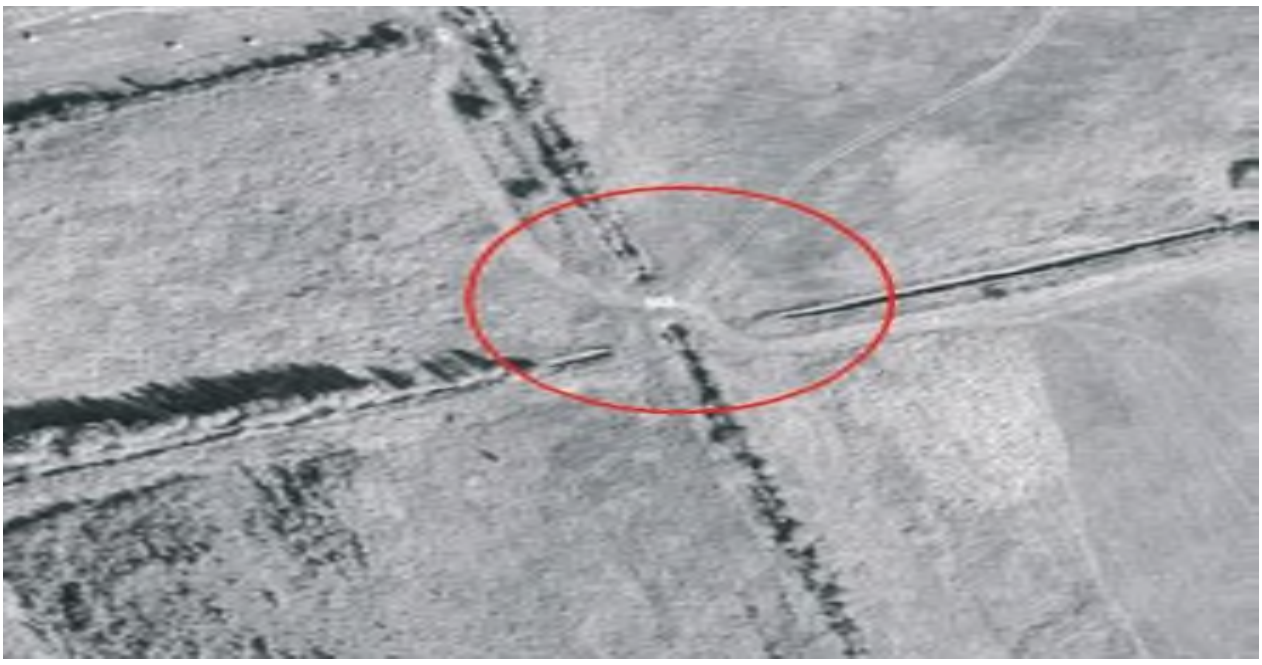

Fig. 3. Overlapping of drainage network channels with earthen dams based on APS materials.

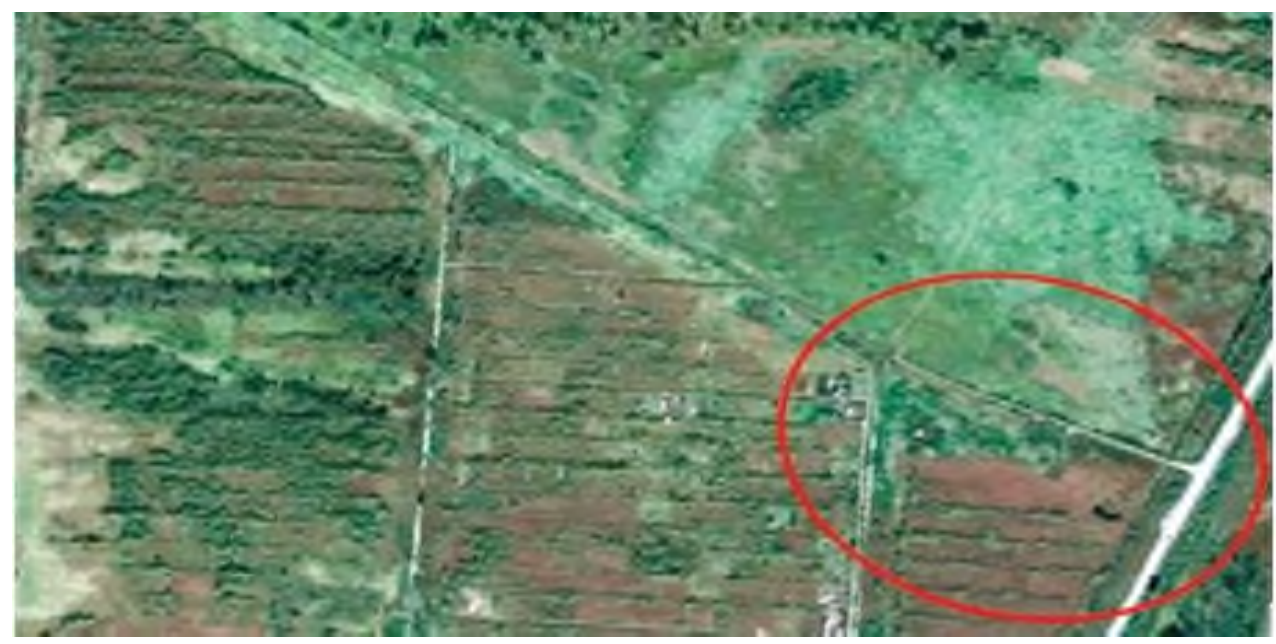

Fig. 4. Construction of transport communications based on the QuickBird satellite imagery.

The operation to drain the Tharman Marshes is not progressing as well as expected. In addition, drained bogs, where peat is no longer being mined, are dangerous - there is no one to keep an eye on the swamps, and any fire threatens to turn into a big disaster.

\section{Conclusion}

In order for the territory to become suitable for building and in the future comfortable and safe for living, it is necessary:

- to develop engineering preparation of the city territory, increasing attention to the areas located in the zone of flooding and waterlogging;

- to carry out timely control over the condition and use of the reclaimed land, in order to identify violations and quality condition;

- to make an inventory of the existing reclamation devices, as well as to register them in the USRR, since with the emergence of the right to them, the rightholders will be responsible for their safety and operation; 
- carry out the reconstruction of drainage channels

- to build dams, and somewhere to relocate summer residents to other territories

\section{References}

1. Federal Law No. 4-FZ of 10.01.1996 "On Land Reclamation" (2020)

2. A. Ermakova, Y. Zubareva, D. Ermakov, Agroprodovolstvennaya politika Rossii 8, 70$72(2012)$

3. A. Ermakova, Y. Zubareva, Strategic development of rural territories in the South of the Tyumen region (Tyumen industrial University, Tyumen, 2017)

4. A. Ermakova, Moscow Economic Journal 10, 50 (2019)

5. A. Ermakova, Moscow Economic Journal 2, 19 (2020)

6. A. Kazakov, Bulletin of the Tyumen State University 4 (2013)

7. V. Novokhatin, Vestnik TSU. Earth Sciences 7(4) (2012)

8. L. Oznobikhina, Moscow Economic Journal 1, 7 (2020)

9. L. Oznobikhina, S. Odintseva, Modern issues of land management, cadastre and land monitoring materials of the regional scientific and practical conference, 125-130 (2016)

10. L. Oznobikhina, Moscow Economic Journal 2, 20 (2020)

11. A. Oznobikhina, L. Oznobikhina, Moscow Economic Journal 1, 8 (2019)

12. Tarmansky swamp massif- a unique creation of nature published by: murashka 12, 56 (2014) http://safe-rgs.ru/711-tarmanskiy-bolotnyy-massiv-unikalnoe-sozdanieprirody.html

13. G. Kozlov, et al. E3S Web of Conferences, 215, 03003 (2020) doi:10.1051/e3sconf/202021503003 